\title{
Feeding behavior of the Neotropical freshwater stingray Potamotrygon motoro (Elasmobranchii: Potamotrygonidae)
}

\author{
Akemi Shibuya ${ }^{1}$, Jansen Zuanon ${ }^{1}$ and Sho Tanaka ${ }^{2}$
}

\begin{abstract}
The feeding mechanisms of elasmobranchs and their functioning have been receiving growing scientific attention, although less emphasis has yet to be directed towards batoid species. The present study investigated the use of orobranchial musculature during prey capture and processing behavior in Potamotrygon motoro. Ten orobranchial muscle groups were removed to determine their relative biomasses. The kinematics of the musculature was described based on videos of prey capture and manipulation under captive conditions recorded at 250 and 500 field/s. Analyses of the orobranchial musculature indicated that adductor muscles responsible for closing the mouth had high biomasses, which is consistent with their functions related to apprehend and manipulate the prey. The feeding behavior adopted by this ray species showed a sequence of manipulation to crush hard prey as crustaceans (dominant prey category for $P$. motoro) to facilitate final oral transport. The morphological and behavioral characteristics of $P$. motoro are essential to fully understanding the mechanisms used in prey capture and processing in environments in which these stingrays occur.
\end{abstract}

Os mecanismos alimentares e suas funções em elasmobrânquios têm recebido crescente atenção, apesar de pouca ênfase ser direcionada às espécies de batoideos. No presente estudo foi investigado o uso da musculatura orobranquial na captura e processamento de presas durante o comportamento alimentar em Potamotrygon motoro. Dez conjuntos de músculos orobranquiais foram removidos para a determinação da massa relativa. A cinemática dos músculos foi descrita a partir de observações da captura e manipulação de presas registradas em 250 e 500 fotogramas/s, sob condições de cativeiro. A análise da musculatura orobranquial indicou que os músculos adutores responsáveis pelo fechamento da boca apresentaram alta biomassa, o qual foi consistente com sua função para a apreensão e manipulação de presas. O comportamento alimentar utilizado por esta raia mostrou uma sequência de manipulação para a quebra de presas com estruturas rígidas como crustáceos (considerados como categoria dominante de presas para P. motoro), facilitando o transporte oral final. As características morfológicas e comportamentais de $P$. motoro são essenciais para a compreensão do uso do mecanismo para a captura e processamento de presas nos ambientes em que essas raias ocorrem.

Key words: Batoidea, Kinematics, Orobranchial musculature, Prey manipulation .

\section{Introduction}

Elasmobranchs feed on a wide variety of organisms and are responsible for energy transfer through trophic levels in all of the environments in which they occur (Wetherbee \& Cortés, 2004). Although these animals have a relatively simple buccal apparatus, they demonstrate various different types of feeding behavior (capture by suction, mandibular apprehension, oral manipulation, and filtration) (Wilga \& Motta, 1998a), and they consume various prey categories (Motta, 2004).
Investigations of the feeding mechanisms of elasmobranchs and their mechanics have been receiving growing attention - but despite rays comprise more than half of all elasmobranch species (Wilga \& Motta, 1998b; Compagno, 2005), research has mostly been focused on shark species due to their voracity (Frazzetta \& Prange, 1987; Wilga \& Motta, 1998a; Wilga \& Motta, 2000; Wilga, 2005). An extensive analysis of the ventral musculature in batoids was undertaken by Miyake et al. (1992), and descriptive studies concerning the cephalic musculature and the cranialmandibular elements were carried out by González-Isáis (2003)

${ }^{1}$ Coordenação de Pesquisas em Biologia Aquática, Instituto Nacional de Pesquisas da Amazônia, INPA, Avenida André Araújo, 2936, Aleixo, 69060-001 Manaus, Amazonas, Brazil. akemi_shibuya@yahoo.com.br; zuanon@inpa.gov.br

${ }^{2}$ Tokai University, School of Marine Science and Technology, 3-20-1 Orido, 424-8610 Shimizu, Shizuoka, Japan. sho@scc.u-tokai.ac.jp 


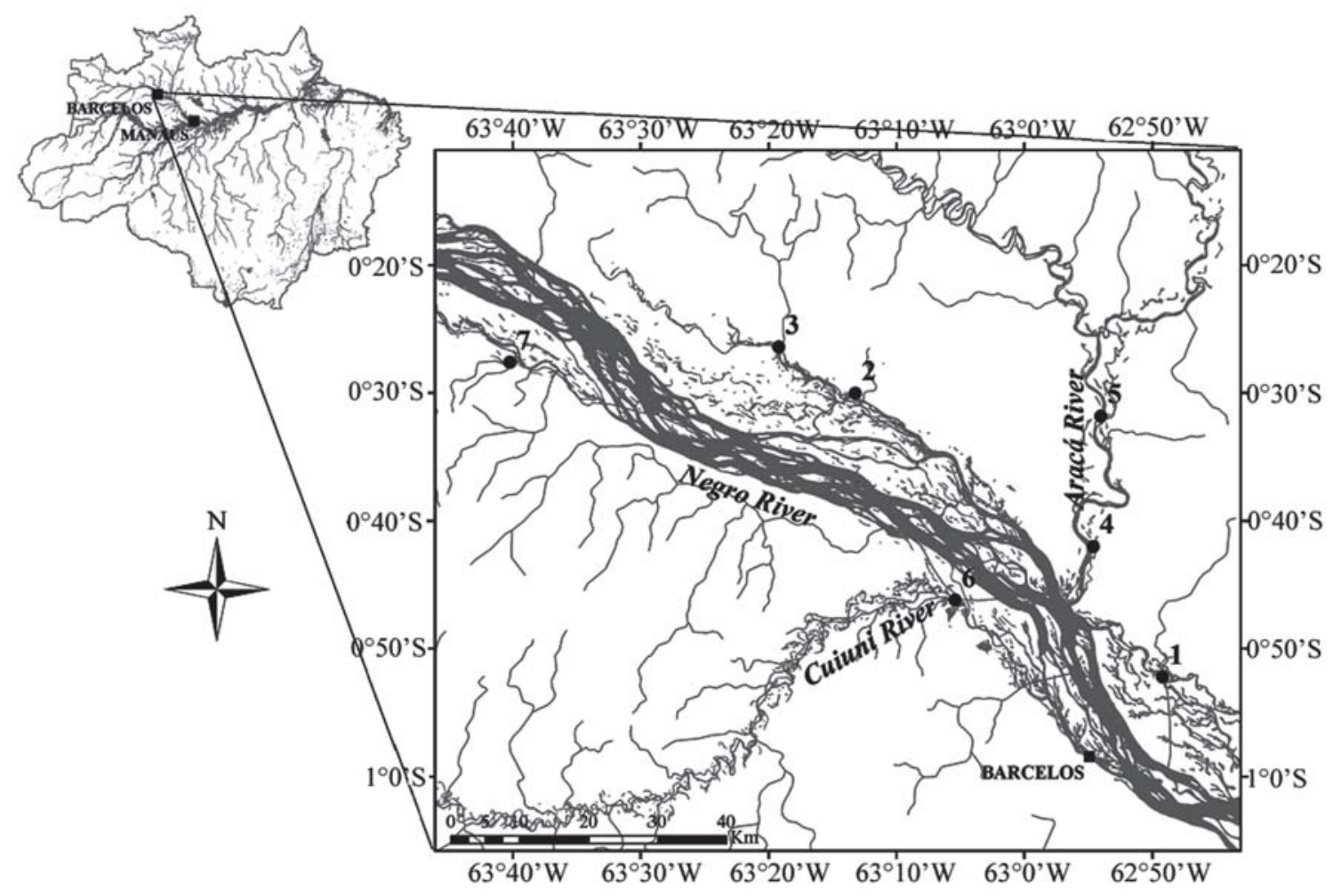

Fig. 1. Sampling locations of specimens of Potamotrygon motoro in the middle Negro River, Barcelos Municipality, Amazonas State, Brazil. 1, Arirahá River; 2, Cuiuni River; 3, Daraquá Stream; 4, Demeni River; 5, Itu River; 6, Maqui Lake; 7, Zamula Stream.

and González-Isáis \& Dominguez (2004) in Myliobatoid rays. All of these studies were basically taxonomic, however, and few inferences were made concerning the functions of their muscles and cartilage during feeding.

Many ray species inhabit coastal environments and shallow water areas, however, there is a notable scarce of studies concerning their feeding behaviors. One factor that makes it difficult to visualize feeding tactics and investigates prey capture and manipulation modes in rays with benthic habits is the ventral position of their mouths; this makes experiments under laboratory conditions essential for detailed observations (e.g. Wilga \& Motta, 1998b; Dean \& Motta, 2004).

Few studies on the functional morphology of Neotropical freshwater stingrays (Potamotrygonidae Garman, 1877) are available, although some general inferences have been made from feeding studies involving a few species (e.g. Lasso et al., 1996; Lonardoni et al., 2006). Likewise, information on the diet and feeding habits of these rays have generally been limited to descriptions of the types of prey they consume (without any mention of the influences of the different feeding mechanisms and the mechanics adopted for prey capture and processing). This is the case of Potamotrygon motoro, a widely distributed species in Neotropical rivers (Compagno \& Cook, 1995; Carvalho et al., 2003). It is an economically important freshwater ray species (especially in the ornamental fishing trade) that consumes a wide variety of prey such as fishes, crustaceans, mollusks, and aquatic insects (e.g. Pantano-Neto, 2001; Lonardoni et al., 2006; Shibuya et al., 2009; Almeida et al., 2010). As many of stingrays, its feeding behavior is unknown. Thus, the current study examined the feeding mechanism (orobranchial musculature) of Potamotrygon motoro and its use during prey capture and manipulation under captive conditions.

\section{Material and Methods}

Orobranchial musculature. Ten specimens of $P$. motoro were obtained from the Middle Negro River in the Barcelos Municipality, Amazonas State, Brazil (Fig. 1) (Freshwater Stingray Monitoring Plan, supported by the Amazonas State Research Funding Agency and coordinated by Maria Lúcia Araújo). All specimens were identified according to Rosa (1985). A voucher specimen was catalogued at the Instituto Nacional de Pesquisas da Amazônia, Manaus, Brazil; INPA 27091. Miological analyses were performed by removing ten muscle groups involved in the feeding process: adductor mandibulae, depressor hyomandibulae, levator palatoquadrati, preorbitalis, spiracularis, depressor mandibulae, levator hyomandibulae, coracomandibularis, coracohyoideus, and coracohyomandibularis, following Marion (1905), Miyake et al. (1992), and Liem \& Summers (1999). The wet-mass values of each muscle were transformed into percentages in relation to the ten muscle groups involved in feeding, according to the 
following equation: $\% \mathrm{Pm}=100 \mathrm{xPm} / \mathrm{Pt}$, where: $\mathrm{Pm}=$ mass of the specific muscle, and $\mathrm{Pt}=$ total mass of the ten orobranchial muscles. Wet mass quantification was adopted to allow comparisons with the studies of Pantano-Neto (2001).

Feeding behavior. Two males of Potamotrygon motoro (disk widths, DW $=14.7 \mathrm{~cm}$ and $15.0 \mathrm{~cm}$ ) were obtained from commercial ornamental fish dealers in Japan (the origin is unknown, probably from Colombia or Brazil) and maintained in an acrylic aquarium $(120 \times 60 \times 60 \mathrm{~cm})$ at $26 \pm 1^{\circ} \mathrm{C}$ on a $10 \mathrm{~L}: 14 \mathrm{D}$
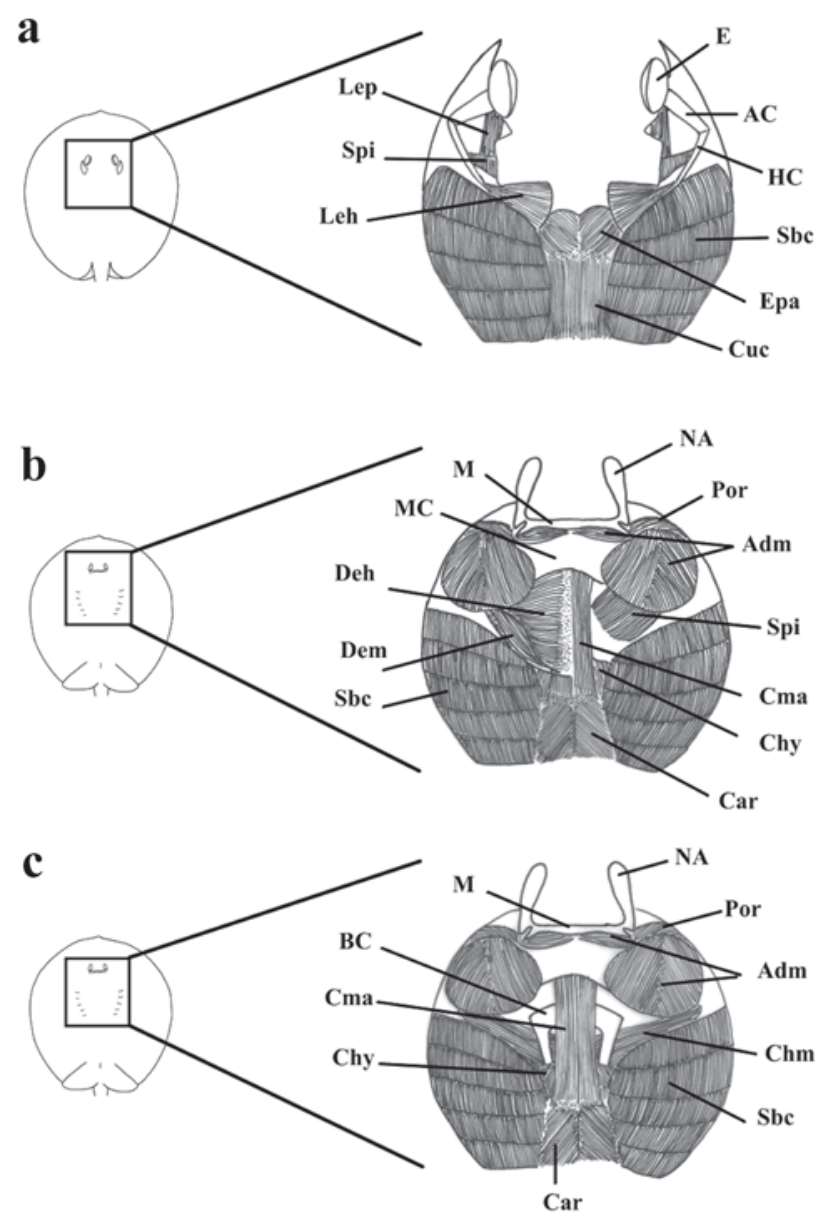

Fig. 2. Cranial musculature of Potamotrygon motoro at dorsal surface (a) and ventral surface (b). The left and right sides show the outer (superficial) and inner (deeper) layers of muscles, respectively. (c) deeper layer of orobranchial musculature in the ventral view, after removing the muscles Dem, Deh and Spi. Adm, adductor mandibulae; AC, angular cartilage; BC, basihyal cartilage; Car, coracoarcualis; Chm, coracohyomandibularis; Chy, coracohyoideus; Cma, coracomandibularis; Cuc, cucullaris; Deh, depressor hyomandibulae; Dem, depressor mandibulae; E, eye; Epa, epaxialis; HC, hyomandibular cartilage; Leh, levator hyomandibulae; Lep, levator palatoquadrati; M, mouth; MC, meckelian cartilage; NA, nostril aperture; Por, preorbitalis; Sbc, superficial branchial constrictor; Spi, spiracularis. DW (disc width) $=18 \mathrm{~cm}$. photoperiodic cycle. The specimens were allowed to acclimate to the aquarium for two days, and after this period they were fed live shrimps once a day (from eight to ten shrimps per ray). Food was offered with the laboratory lighting turned on, and at regular times.

Feeding behavior was recorded in 13 sequences using two high-speed synchronized video cameras (Phantom v4.2 and Miro 3) at 250 and 500 fields/s. One camera was positioned to film from the lateral side of the aquarium, while a second camera was oriented towards a $50 \times 50 \mathrm{~cm}$ mirror placed at a $45^{\circ}$ angle under the transparent bottom of the aquarium (to record the ventral portion of the ray). During filming, the aquarium was illuminated by two $500 \mathrm{w}$ quartz-halogen floodlights, one positioned near each of the cameras. Simultaneous recording of the feeding behavior by these two cameras was guaranteed by the use of a synchronizer. A 2 x 2 $\mathrm{cm}$ grid was drawn on the rear wall of the aquarium to aid in determining the spatial orientations of the animals. The quantity of food supplied to the individual rays was reduced one day before the experiment to stimulate their feeding. The time elapsed during the prey capture and manipulation were calculated in milliseconds (ms) based on counting the fields of the recorded images (one field $=4 \mathrm{~ms}$ or $2 \mathrm{~ms}$, at 250 and 500 fields/s respectively) (see Motta et al., 2002).

\section{Results}

Orobranchial musculature. The distribution of the muscle groups of $P$. motoro and their relative positions are illustrated in Fig. 2. Table 1 compares the relative wet masses of the muscles involved in the feeding processes of the specimens of $P$. motoro from the Negro River with those presented by Pantano-Neto (2001) for specimens from a tributary of the Araguaia River (Cristalino River). In the present study, $P$. motoro demonstrated greater relative masses of the levator palatoquadrati (used to open the mouth), preorbitalis and adductor mandibulae (providing more power to close the mouth) muscles, while Pantano-Neto (2001) found greater values for the spiracularis, and coracohyoideus muscles (used in suction movements).

Table 1. Comparison of the relative wet biomass (\%) between specimens of Potamotrygon motoro analyzed by PantanoNeto (2001) and by the current study.

\begin{tabular}{lcc}
\hline Muscles & Pantano-Neto (2001) & (current study) \\
& $\mathrm{N}=8$ & $\mathrm{~N}=10$ \\
\hline adductor mandibulae & 10.08 & 23.36 \\
coracomandibularis & 5.79 & 6.89 \\
coracohyomandibularis & 11.31 & 12.44 \\
coracohyoideus & 2.76 & 1.70 \\
depressor hyomandibulae & 15.79 & 13.46 \\
depressor mandibulae & 1.04 & 1.91 \\
levator hyomandibulae & 6.29 & 5.79 \\
levator palatoquadrati & 5.63 & 12.02 \\
preorbitalis & 7.20 & 16.43 \\
spiracularis & 34.12 & 6.00 \\
\hline
\end{tabular}




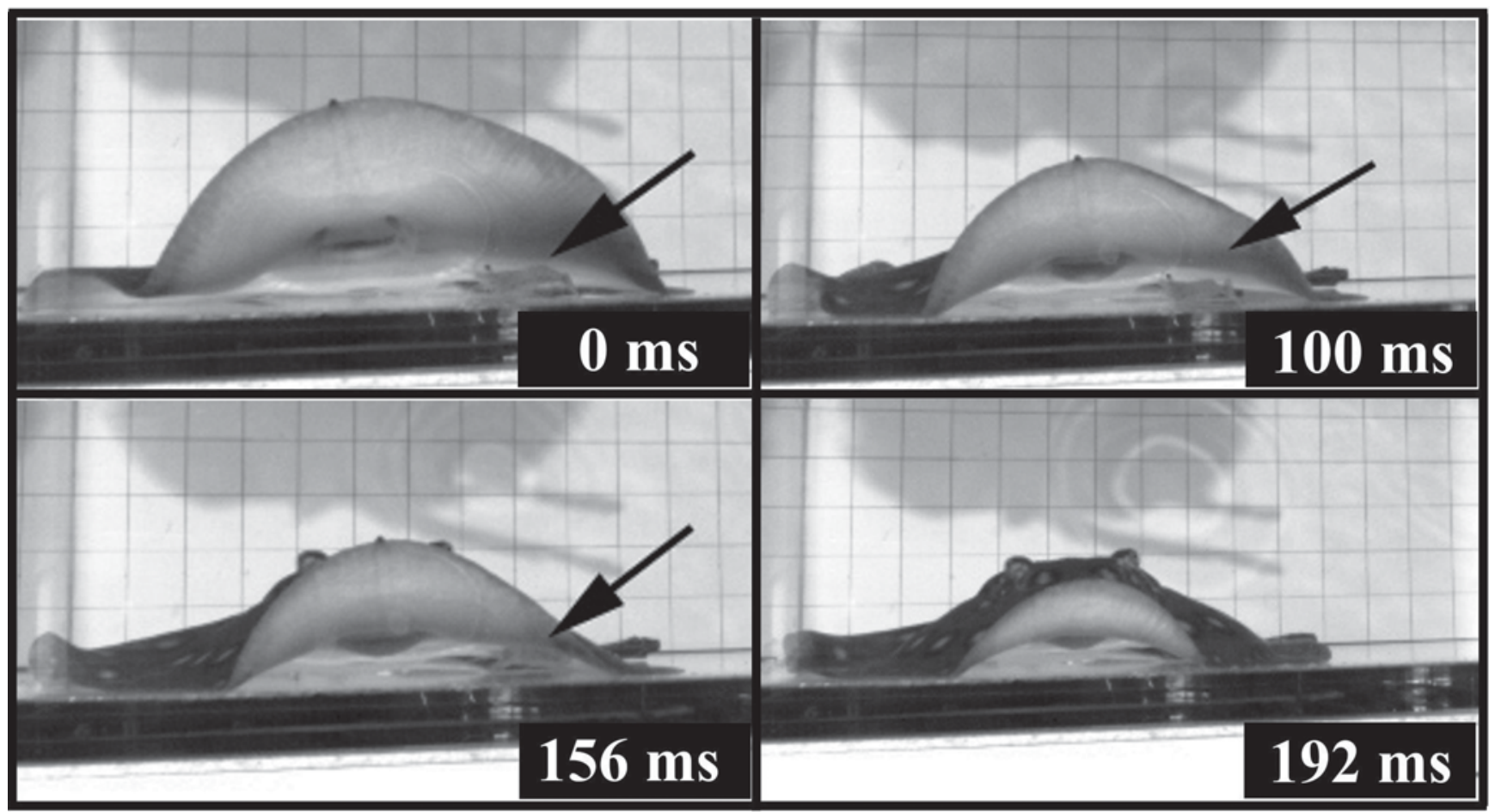

Fig. 3. Sequences of video frames showing the prey capture behavior by Potamotrygon motoro in lateral view. The ray elevates its rostrum $(0 \mathrm{~ms})$, which is followed by depression of lower jaw (100 - $156 \mathrm{~ms})$ and rostrum $(192 \mathrm{~ms})$ to strike the prey. Arrows indicate the prey position.

Feeding behavior. Attack is the first stage of prey capture (Fig. 3), and involves the elevation of the rostrum followed by protrusion of the upper jaw (palatoquadrate cartilage) and depression of the lower jaw (meckelian cartilage) (Fig. 3, in $100-156 \mathrm{~ms}$ ). These movements increase the orobranchial area and facilitate prey capture. An initial attack might not always be immediately followed by a prey strike, and the prey may remain trapped under the ray's body. New attempts at prey striking are made by the ray by maintaining its rostrum, pectoral and pelvic fins pressed against the bottom to inhibit escape, increasing their body height by up to $20 \%$ and creating a chamber over the prey. The ray will then reorient its body, bringing its mouth nearer to the prey, followed by mouth opening to grasp it.

All prey capture events observed were achieved through prey apprehension, except for a single suction-capture event. Strike capture was characterized by upper jaw protrusion and lower jaw depression to keep the prey between the jaws. In the single case of capture by suction, this behavior was followed by bite manipulation of the prey within the oral cavity until final oral transport.

Oral manipulation was observed in eight feeding events and was characterized by biting movements while maintaining the prey partially outside of the mouth (Fig. 4). This sequence lasted an average of $2394 \mathrm{~ms} \pm 1537 \mathrm{SD}(1096$ - $5896 \mathrm{~ms} ; \mathrm{n}=8)$. Oral manipulation involved one or more sequences of prey expulsion and suction (Fig. 4, 1604 - $3604 \mathrm{~ms}$ ) to process the prey, incapacitate it, and prevent its escape. Manipulation was finalized by suction, lasting an average of $147 \mathrm{~ms} \pm 37 \mathrm{SD}$ $(108-216 \mathrm{~ms} ; \mathrm{n}=8)$ (Fig. 4, 3688 - $3801 \mathrm{~ms})$. After prey manipulation, the biting movements continued with the prey totally inside the buccal cavity. These movements then ceased and the feeding event is closed, supposing that the food is transported to the esophagus. The behavioral sequences of the feeding process are summarized in the flow chart in Fig. 5.

Musculature performance during feeding activities. The actions of the orobranchial muscles and the kinematics of the cranial elements during prey apprehension are illustrated in Fig. 6. The depression of the mandible (meckelian cartilage) (Fig. 6a) is generated by depression of the hyomandibular cartilage and mouth opening. During the process of mouth opening the basihyal cartilage is also depressed, increasing the volume of the buccal-pharyngeal cavity. Upper jaw protrusion (palatoquadrate cartilage) then occurs, followed by a caudal-directed movement of the meckelian cartilage. Prey apprehension is initiated with the depression of the hyomandibular cartilage that is driven by the depressor hyomandibulae muscle.

The depression of the hyomandibular cartilage results in mouth opening (driven by the depressor mandibulae muscle that acts simultaneously with the coracomandibularis muscle to depress the meckelian cartilage). The coracohyomandibularis muscle is responsible for depressing the basihyal cartilage and acts simultaneously with the depressor hyomandibulae muscles to increase the volume of 


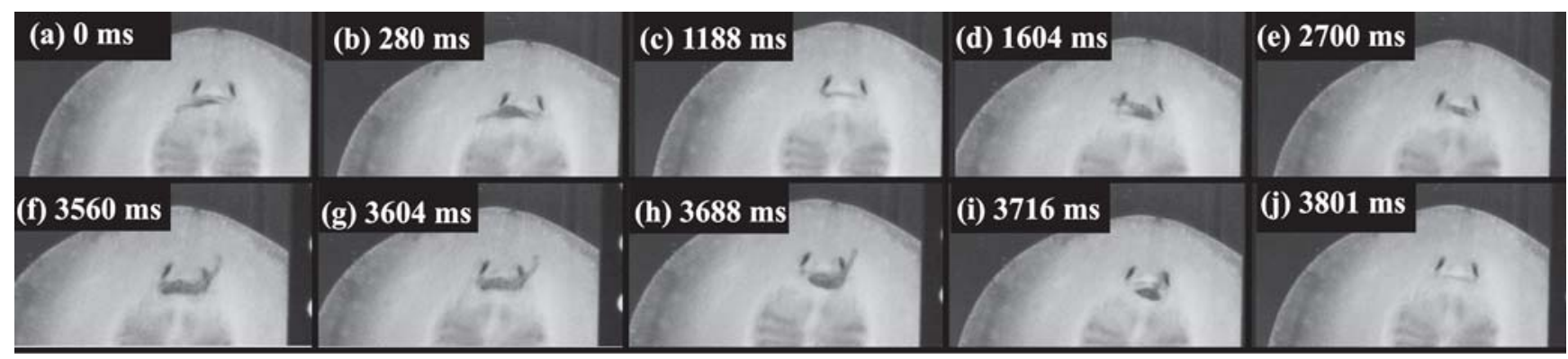

Fig. 4. Sequences of video frames showing prey manipulation by individual of Potamotrygon motoro in ventral view. Sequential time is indicated in each frame in milliseconds (ms). The sequence shows the prey capture (a) and its partial expel (b - c), followed by bite manipulation $(\mathbf{d}-\mathbf{g})$. The ingestion occurs after total suction of prey $(\mathbf{h}-\mathbf{i})$, then oral transport (j). Arrow indicates the prey position.

the buccal-pharyngeal cavity (Fig. 6b). Protrusion of the upper jaw (palatoquadrate cartilage) occurs as a consequence of the maximum depression of the meckelian cartilage. This type of movement is mediated by the preorbitalis muscle and is followed by the activation of the coracomandibularis muscle during mouth opening and by the caudal-directed movement of the meckelian cartilage (Fig. 6c).

Mouth closing during prey apprehension occurs through the activation of the adductor mandibulae complex, with the approximation of the palatoquadrate and meckelian cartilage, finalizing the capture sequence. The depressor hyomandibulae, coracohyomandibularis, and coracohyoideus muscles appear to contribute to prey capture by suction by rapidly increasing the internal volume of the buccal-pharyngeal cavity. These suction movements also depend on the contribution of the spiracularis muscle that closes the spiracle in order to allow the internal pressure of the buccal-pharyngeal cavity to increase.

\section{Discussion}

An interpretation of the functional morphology of the feeding mechanisms of Potamotrygon motoro was possible based on our understanding of its feeding habits (Shibuya et al., 2009). There is evidence for differences in the feeding habits of distinct populations of P. motoro (e.g. Pantano-Neto, 2001; Lonardoni et al., 2006; Almeida et al., 2010) that are influenced by differential abundances of certain prey categories in the environments in which these stingrays occur. Consequently, this fact can require different actions of each orobranchial muscles. Earlier studies of the diet and feeding habits of $P$. motoro reported that a large variety of prey types are consumed, such as aquatic insects, mollusks, crustaceans, and fishes (Pantano-Neto, 2001; Lonardoni et al., 2006; Garrone-Neto et al., 2007; Silva \& Uieda, 2007; Almeida et al., 2010), with differing levels of importance of each category. Potamotrygon motoro from the Negro River basin consumed these same prey categories (Shibuya et al., 2009), although the rare occurrence of mollusks in their stomach contents apparently reflected the limited occurrence of this prey type in this dark fresh water (Sioli, 1953; Volkmer-Ribeiro et al., 1998).
Shibuya et al. (2009) analyzed the stomach contents of three additional potamotrygonid species (Potamotrygon orbignyi, Potamotrygon sp. "cururu", and Paratrygon aiereba) that co-occur in the Negro River and reported that

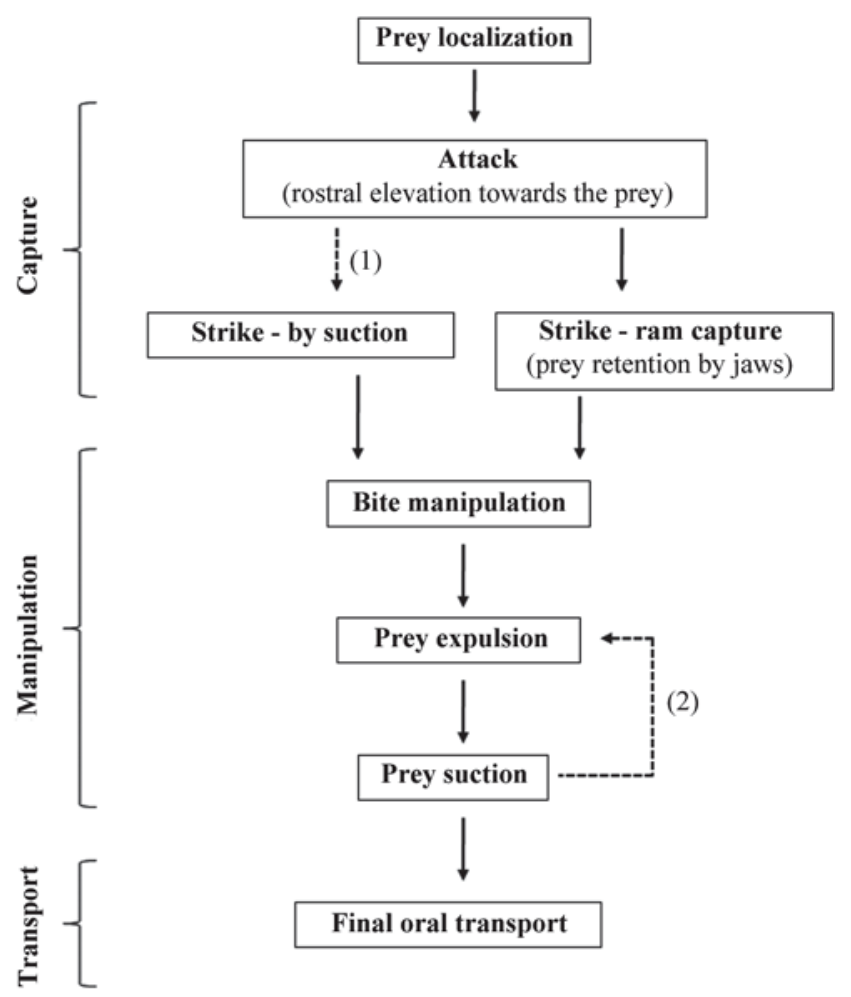

Fig. 5. Flow chart representing the feeding behavior of Potamotrygon motoro under captive conditions. After attack, prey capture by suction was observed (1) in one event; strike capture was used in a majority of the feeding events. During bite manipulation, a sequence of repeated expelling and suction events occurred (2) in four observed cases. This manipulation was followed by final oral transport, with the transport of the food item from the buccal cavity to the esophagus. Dashed arrow $=$ an occasional alternative sequence. $\mathrm{N}=13$ observed sequences. 
a

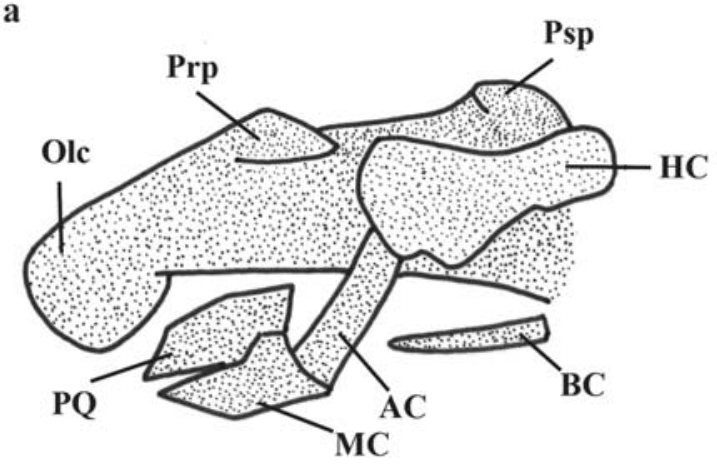

b

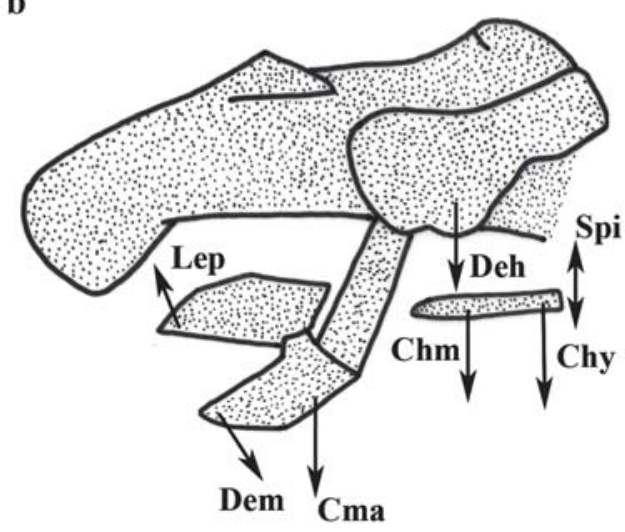

c

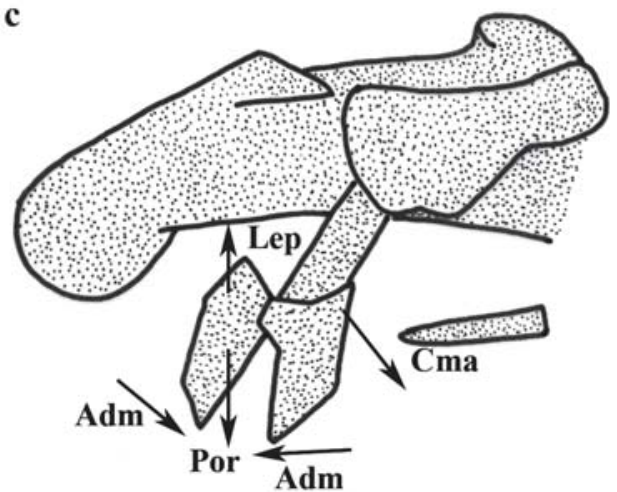

Fig. 6. Lateral view of the cranium of Potamotrygon motoro, showing the jaws movements during prey capture. From the resting position (a), mandibular, hyomandibular and basihyal cartilages depress and the mouth opens (b), followed by jaw protrusion. (c) The mouth closes after prey apprehension. Arrows indicate the direction of each muscles action. Adm, adductor mandibulae; AC, angular cartilage; BC, basihyal cartilage; Car, coracoarcualis; Chm, coracohyomandibularis; Chy, coracohyoideus; Cma, coracomandibularis; Cuc, cucullaris; Deh, depressor hyomandibulae; Dem, depressor mandibulae; E, eye; Epa, epaxialis; HC, hyomandibular cartilage; Leh, levator hyomandibulae; Lep, levator palatoquadrati; M, mouth; MC, meckelian cartilage; NA, nostril aperture; Por, preorbitalis; Sbc, superficial branchial constrictor; Spi, spiracularis. the differences observed in their feeding habits were probably related to the particular environments each species utilized during foraging, although they could likewise reflect spatial variations in the abundance and natural availability of their prey. Another factor that can influence their feeding habits is the use of different types of feeding mechanisms (Wilga \& Motta, 1998b; Maruska, 2001; Motta, 2004), mainly on sensorial systems (electro- and mechanoreception) for localization and orientation during foraging for buried prey.

Two prey capture modes were described for elasmobranchs: suction and strike, with both of them being followed by bite manipulation. Elasmobranchs capture their prey using one of these modes or by combinations of both (Wilga \& Motta, 1998a). This capture behavior differentiation was examined by FerryGraham (1998) and Wilga \& Motta (1998a) who demonstrated that capture tactics are modified depending on prey types and sizes. Strike was the predominant tactic employed during the observations of $P$. motoro reported here, with suction being observed during only a single feeding event. We are not able to affirm, however, that strike is the primary capture mode in $P$. motoro because there was not sandy substrate on the bottom of the aquarium to bury the prey. The presence of this kind of substrate may provide distinct foraging behavior, as well as observed by Sasko et al. (2006) for the cownose ray Rhinoptera bonasus (Rhinopteridae).

Differences in the feeding habits among different populations of Potamotrygon motoro (Pantano-Neto, 2001; Lonardoni et al., 2006; Shibuya et al., 2009; Almeida et al., 2010) may result in differences in the strike and manipulation movements as a result of variations in the relative masses of the different muscle groups. Pantano-Neto (2001) demonstrated that the depressor hyomandibulae and spiracularis muscles in P. motoro (which increase the size of the buccal cavity and aid in prey suction) had the greatest mass values due to their use in the suction-capture of aquatic insects (which were the dominant items in the diet of this population); different results were found here. Specimens of P. motoro from the Negro River had high mass values for the adductor muscles (adductor mandibulae and preorbitalis) responsible for closing the mouth during the manipulation of hard prey (to facilitate their ingestion, as in the case of crustaceans). Shibuya et al. (2009) demonstrated that $P$. motoro from the Negro River mainly consumes hard prey (such as trichodactylid crabs); this prey is found with crushed shells, corroborating the presumed use of the powerful adductor muscles of these batoids during prey manipulation.

Different from the observations of Dean \& Motta (2004) for Narcine brasiliensis (Narcinidae) and of Sasko et al. (2006) for Rhinoptera bonasus, P. motoro does not winnow prey that may have an outer shell and ingest only relatively easily digestible material with high nutritional value. As this type of material separation was not observed in $P$. motoro, the depressor mandibulae muscle may contribute to widening the opening of the buccal-pharyngeal cavity, thus facilitating the passage of largely intact prey. The observed sequences of partial expulsion and suction 
during oral manipulation in these individuals were apparently designed to crush large hard prey to facilitate the ingestion and final oral transport (aided by depressor mandibulae). Prey manipulation behavior followed by final suction and oral transport was observed in all of the feeding events recorded. Wilga \& Motta (1998b) defined this final suction as transport by suction, thus constituting an additional sequence in oral transport behavior.

Field observations of the feeding behavior of an individual of Potamotrygon orbignyi made in the Xingu River (J. Zuanon, pers. observ.) indicated that this ray species resuspended the sandy sediments using pectoral and pelvic fin movements (and possibly by expelling water from its mouth) to aid in prey localization, and to uncover and capture it. The water taken in with the prey was subsequently expelled through the branchial openings and spiracles (as could be judged by visible valve-opening activity).

In spite of the fact that these observations were made with $P$. orbignyi in the natural environment, the same type of behavior has been commonly observed in many species of Potamotrygonidae, including P. motoro (e.g. Garrone-Neto \& Sazima, 2009). It is obvious that observations of feeding behavior made solely under captive conditions will not yield complete information about the mechanics of prey capture and processing, and field investigations will be necessary to resolve many details.

The results obtained in the present study with Potamotrygon motoro demonstrate the importance of analyzing feeding data and foraging, prey capture, and manipulation behavior together with studies of batoid morphological characteristics. It is clear that feeding habits and the functionality of feeding mechanisms of $P$. motoro should not be defined based solely on information obtained from just a few specimens under laboratory conditions, nor can generalizations be made about the feeding mechanisms of all of its populations as this species is known to consume a wide variety of prey types. However, the information presented here is essential for a better understanding of the feeding mechanisms of $P$. motoro and its trophic role in freshwater ecosystems.

\section{Acknowledgements}

We are indebted to Maria Lúcia Góes de Araújo (UEA, Brazil) for kindly providing samples of Potamotrygon motoro; Eliana Feldberg (INPA, Brazil) for the use of the drying oven; to the graduate and undergraduate students in the laboratory of School of Marine Science and Technology (Tokai University, Japan) for taking care of the living rays during the study period; and Mason Dean (Max-Planck Institute, Germany) for valuable contribution for the feeding behavior studies. The work of the first author was supported by a research grant from the Japan International Cooperation Agency (JICA). A S and JZ thank the Conselho Nacional de Desenvolvimento Científico e Tecnológico $(\mathrm{CNPq})$ for their respective doctoral and productivity (process \# 307464/2009-1) grants.

\section{Literature Cited}

Almeida, M. P., P. M. O. Lins, P. Charvet-Almeida \& R. B. Barthem. 2010. Diet of the freshwater stingray Potamotrygon motoro (Chondrichthyes: Potamotrygonidae) on Marajó Island (Pará, Brazil). Brazilian Journal of Biology. 70: 155-162.

Carvalho, M. R., N. R. Lovejoy \& R. S. Rosa. 2003. Family Potamotrygonidae (River stingrays). Pp. 22-28. In: Reis, R. E., S. O. Kullander \& C. J. Ferraris-Junior (Eds.) Check list of the freshwater fishes of South and Central America. Edipucrs. Porto Alegre, 729p.

Compagno, L. J. V. 2005. Checklist of living Chondrichthyes. Pp. 503-548. In: Hamlett, W. C. (Ed.) Reproductive biology and phylogeny of Chondrichthyes: sharks, batoids and chimaeras. Science Publishers, Enfield.

Compagno, L. J. V. \& S. F. Cook. 1995. The exploitation and conservation of freshwater elasmobranchs: status of taxa and prospects for the future. Journal Aqua \& Aquatic Sciences: The biology of freshwater elasmobranchs. pp: 62-90.

Dean, M. \& P. J. Motta. 2004. Feeding behavior and kinematics of the lesser electric ray, Narcine brasiliensis (Elasmobranchii: Batoidea). Zoology, 104: 171-189.

Ferry-Graham, L. A. 1998. Effects of prey size and mobility on prey-capture kinematics in leopard sharks Triakis semifasciata. Journal of Experimental Biology, 201: 2433-2444.

Frazzetta, T. H. \& C. D. Prange. 1987. Movements of cephalic components during feeding in some requiem sharks (Carcharhiniformes: Carcharhinidae). Copeia, 1987: 979-993.

Garrone-Neto, D., V. Haddad-Jr, M. J. A. Vilela \& V. S. Uieda. 2007. Registro de ocorrência de duas espécies de potamotrigonídeos na região do Alto Rio Paraná e algumas considerações sobre sua biologia. Biota Neotropica. http://www.biotaneotropica.org.br/ v7n1/pt/fullpaper?bn00707012007.

Garrone-Neto, D. \& I. Sazima. 2009. Stirring, charging, and picking: hunting tactics of potamotrygonid rays in the upper Paraná River. Neotropical Ichthyology, 7: 113-116.

González-Isáis, M. 2003. Anatomical comparison of the cephalic musculature of some members of the superfamily Myliobatoidea (Chondrichthyes): Implications for evolutionary understanding. The Anatomical Record Part A, 271: 259-272.

González-Isáis, M. \& H. M. M. Dominguez. 2004. Comparative anatomy of the superfamily Myliobatoidea (Chondrichthyes) with some comments on phylogeny. Journal of Morphology, 262: 517-535.

Lasso, C. A., A. B. Rial \& O. Lasso-Alcalá. 1996. Notes on the biology of the freshwater stingrays Paratrygon aiereba (Müller and Henle, 1841) and Potamotrygon orbignyi (Castelnau, 1855) (Chondrichthyes: Potamotrygonidae) in the Venezuelan llanos. Aqua Journal of Ichthyology and Aquatic Biology, 2: 39-52.

Liem, K. F. \& A. P. Summers. 1999. Muscular system: gross anatomy and functional morphology of muscles. Pp. 93-114. In: Hamlett, W. C. (Ed.) Sharks, skates and rays, the biology of elasmobranch fishes. The John Hopkins University Press. Baltimore, Maryland.

Lonardoni, A. P., E. Goulart, E. F. Oliveira \& M. C. F. Abelha. 2006. Hábitos alimentares e sobreposição trófica das raias Potamotrygon falkneri e Potamotrygon motoro (Chondrichthyes, Potamotrygonidae) na planície alagável do alto rio Paraná, Brasil. Acta Scientiarum Biological Sciences, 3: 195-202.

Marion, G. E. 1905 Mandibular and pharyngeal muscles of Acanthias e Raia. American Naturalist, 39: 891-920. 
Maruska, K. P. 2001. Morphology of the mechanosensory lateral line system in elasmobranch fishes: ecological and behavioral considerations. Environmental Biology of Fishes, 60: 47-75.

Miyake, T., J. D. McEachran \& B. K. Hall. 1992. Edgeworth's legacy of cranial muscle developments with an analysis of muscles in the ventral gill arch region of batoid fishes (Chondrichthyes: Batoidea). Journal of Morphology, 212: 213-256.

Motta, P. J. 2004. Prey capture behavior and feeding mechanics of elasmobranchs. Pp. 165-202. In: Carrier, J. C., J. A. Musick \& M. R. Heithaus (Eds.) Biology of Sharks and Their Relatives. CRC Press. Boca Raton.

Motta, P. J., R. E. Hueter, T. C. Tricas \& A. P. Summers. 2002. Kinematic analysis of suction feeding in the nurse shark, Ginglymostoma cirratum (Orectolobiformes, Ginglymostomatidae). Copeia, 2002: 24-38.

Pantano-Neto, J. 2001. Estudo preliminar da anatomia descritiva e funcional associada à alimentação em raias de água-doce (Potamotrygonidae, Myliobatiformes, Elasmobranchii). Unpublished M.Sc. Dissertation. Universidade de São Paulo, São Paulo, 92p.

Rosa, R. S. 1985. A systematic revision of the South American freshwater stingrays (Chondrichthyes: Potamotrygonidae). Unpublished Ph.D. Dissertation. College of William and Mary, Virginia, 523p.

Sasko, D. E., M. N. Dean, P. J. Motta \& R. E. Hueter. 2006. Prey capture behavior and kinematics of the Atlantic cownose ray, Rhinoptera bonasus. Zoology, 109: 171-181.

Shibuya, A., M. L. G. Araújo \& J. A. S. Zuanon. 2009. Analysis of stomach contents of freshwater stingrays (Elasmobranchii: Potamotrygonidae) from the middle Negro River, Amazonas, Brazil. Pan-American Journal of Aquatic Sciences, 4: 466-465.
Silva, T. B. \& V. S. Uieda. 2007. Preliminary data on the feeding habits of the freshwater stingrays Potamotrygon falkneri and Potamotrygon motoro (Potamotrygonidae) from the Upper Paraná River basin, Brazil. Biota Neotropica, 7: 221-226.

Sioli, H. 1953. Schistosomiasis and limnology in the Amazon region. American Journal of Tropical Medicine and Hygiene. 2(4): 700707.

Volkmer-Ribeiro, C., M. C. D. Mansur, P. A. S. Mera \& S. M. Ross. 1998. Biological Indicators in the Aquatic Habitats of the Ilha de Maracá. Pp. 403-414. In: Milliken, W. \& J. A. Ratter (Eds.) Maracá: The biodiversity and environment of an Amazonian rainforest. John Wiley \& Sons Ltd.

Wetherbee, B. M. \& E. Cortés. 2004. Food consumption and feeding habits. Pp. 223-243. In: Carrier, J. C., J. A. Musick \& M. R. Heithaus (Eds.) Biology of Sharks and Their Relatives. CRC Press. Boca Raton.

Wilga, C. D. 2005. Morphology and evolution of the jaw suspension in lamniform sharks. Journal of Morphology, 265: 102-119.

Wilga, C. D. \& P. J. Motta. 1998a. Conservation and variation in the feeding mechanism of the spiny dogfish Squalus acanthias. Journal of Experimental Biology, 201: 1345-1358.

Wilga, C. D. \& P. J. Motta. 1998b. Feeding mechanism of the Atlantic guitarfish Rhinobatos lentiginosus: modulation of kinematics and motor activity. Journal of Experimental Biology, 2001: 3167-3184.

Wilga, C. D. \& P. J. Motta. 2000. Durophagy in sharks: Feeding mechanics of the hammerhead Sphyrna tiburo. Journal of Experimental Biology, 203: 2781:2796.

Submitted July 12, 2011

Accepted October 17, 2011

Published March 30, 2012 